HORTICULTURE

\title{
Response of Different Plant Growth Regulators on Fruit Yield of Brinjal
}

\author{
Jellan Kropi ${ }^{1 *}$ and Amit Phonglosa ${ }^{2}$
}

${ }^{1}$ Department of Horticulture, Biswanath College of Agriculture, Assam Agricultural University, Biswanath Chariali-784176, Sonitpur, Assam, India

${ }^{2}$ Directorate of Extension Education, Odisha University of Agriculture and Technology, Bhubaneswar, 751003, Odisha, India

"Corresponding author: soilamit12@rediffmail.com (ORCID ID: 0000-0001-6647-0281)

Paper No. 827

Received: $12-01-2020$

Revised: 15-04-2020

Accepted: 22-05-2020

\begin{abstract}
The experiment was conducted at Instructional cum Research Farm, Department of Horticulture, Biswanath College of Agriculture (AAU) Biswanath Chariali, Sonitpur district of Assam during 2014-15 in order to study the response of plant growth regulators on physiogical and fruit yield of brinjal (Solanum melongena L.) cv. JC -1. The experiment was laid out in a Randomized Block Design with ten treatments replicated three times. The details of treatment comprised of $\mathrm{GA}_{3}(25,50$ and $100 \mathrm{ppm})$, IAA (25, 50 and $100 \mathrm{ppm})$, NAA (25, 50 and $100 \mathrm{ppm}$ ) and control (distilled water). During the period of investigation the growth regulators showed significant response on physiological and yield attributing characters of brinjal. The result revealed that the maximum leaf area index (2.82) was recorded under $\mathrm{GA}_{3}$ at100 ppm $\left(\mathrm{T}_{3}\right)$ while $\mathrm{GA}_{3}$ at $50 \mathrm{ppm}\left(\mathrm{T}_{2}\right)$ recorded the highest $(802.40 \mathrm{~g})$ total dry weight per plant at harvest. However, the highest leaf chlorophyll content index (44.50) was recorded under treatment with NAA at 50 ppm $\left(\mathrm{T}_{8}\right)$. Foliar application $\mathrm{GA}_{3}$ at $50 \mathrm{ppm}\left(\mathrm{T}_{2}\right)$ exhibited significantly higher total number of flower per plant (38.49), number of fruit per plant (18.56) and fruit yield (1.58 kg plant ${ }^{-1}$ and $\left.377.00 \mathrm{q} \mathrm{ha}^{-1}\right)$. It may be concluded from the experiments that $\mathrm{GA}_{3}$ proved to be the best in improving the physiological and yield attributing parameters in brinjal.
\end{abstract}

\section{Highlights}

( Foliar application of $\mathrm{GA}_{3}$ proved to be the best in improving the physiological and yield attributing parameters in brinjal as compared to other growth regulators like IAA and NAA, respectively.

Keywords: Brinjal, plant growth regulators, fruit yield

Brinjal (Solanum melongena L.) is a widely adaptive and highly productive vegetable crop of tropical and subtropical regions world (Kaur et al. 2004). It is one of the most common, popular and principal vegetable crops grown throughout the country except higher altitudes in India. It is a perennial but grown commercially as an annual crop. The maximum potential yield of brinjal is not achieved due to its poor physiological efficiency; poor fruit setting, poor plant architecture and none synchronize maturity (Bhatia et al. 2015). Application of plant growth regulators (PGRs) may play an important role in proper flowering, fruit setting, synchronize maturity, ripening and thereby increase in the physiochemical efficiency and yield of the crops. One of the major problem associated with brinjal are flower and fruit drop resulting in poor fruit yield. The market demand and consumer preference of brinjal depends upon fruit colour, shape, size and stage of maturity (Gopalan et al. 2007). Use of PGRs may increase the productivity of brinjal in terms of quantity and quality, and thereby increase the market price and profitability. Since brinjal is a popular vegetable in India, therefore yield and quality improvement of the crop is of considerable importance. The PGRs 
play an important role in improvement of quality besides improving the productivity. Therefore, the present investigation has been undertaken to find out the suitable plant growth regulators for increasing the yield potential in brinjal.

\section{MATERIALS AND METHODS}

An experiment was conducted at Instructional cum Research Farm, Department of Horticulture, Biswanath College of Agriculture (Assam Agricultural University) Biswanath Chariali, Sonitpur district of Assam during 2014-15. The experimental site was situated at $26^{\circ} 43^{\prime} 32^{\prime \prime} \mathrm{N}$ latitude and $93^{\circ} 08^{\prime} 01^{\prime \prime} \mathrm{E}$ longitude having an elevation of $86.70 \mathrm{~m}$ above mean sea level. The soil of the experimental site is derived from the alluvial deposits of the river Brahmaputra. The experiment was laid out in a Randomized Block Design (RBD) with ten treatments replicated three times depicted in Table 1. Three plant growth regulators namely, $\mathrm{GA}_{3}$ (25, 50 and $\left.100 \mathrm{ppm}\right)$, IAA (25, 50 and $\left.100 \mathrm{ppm}\right)$ and NAA (25, 50 and 100 ppm) were selected for the experiment. Each growth regulators was used in three concentrations at 40 days after transplanting when one or two flower buds appear in each plots. The Brinjal variety JC-1 was selected as test crop. The fruit are elongated, medium sized, purple with pointed apex, maturity 130 days, no incidence of phomopsis blight and little leaf virus, wilt and borer infestation are moderate. The healthy seedling were transplanting one month after sowing at the spacing of $75 \mathrm{~cm} \times 60 \mathrm{~cm}$. During the time of experimentation the observation were recorded from five representative plants in each replication for each treatment. The physiological and yield parameters were counted at 40,60 days after transplanting and at harvest.

\section{Statistical interpretation}

The data were analyzed statistically by the analysis of variance technique using SPSS (version 18.0 Chicago, USA)

\section{RESULTS AND DISCUSSION}

\section{Effect on physiological characters}

The data depicted in Table 1 indicated that leaf area index (LAI) and total dry matter at harvest were found maximum with foliar application of $\mathrm{GA}_{3}$ while the minimum was recorded in control (Table 1). Rahman et al. (2004) also observed that application $\mathrm{GA}_{3}$ increases the LAI and total dry matter production. This might be due to acceleration of vegetative growth resulting in an extensive photosynthetic apparatus and relative increase in LAI by $\mathrm{GA}_{3}$. Similar result was reported by Hoque and Haque (2002) in mung bean and Chatterjee and Choudhuri (2012) in cowpea.

Table 1: Effect of plant growth regulators on physiological and yield parameters at different stage in Brinjal

\begin{tabular}{|c|c|c|c|c|c|c|c|c|}
\hline \multirow[t]{2}{*}{ Treatments } & \multicolumn{2}{|c|}{ Leaf area index } & \multicolumn{2}{|c|}{$\begin{array}{l}\text { Chlorophyll } \\
\text { Content Index }\end{array}$} & \multirow{2}{*}{ 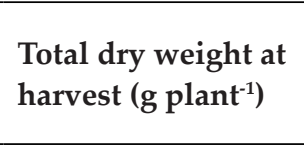 } & \multirow{2}{*}{$\begin{array}{l}\text { No. of fruit } \\
\text { per plant }\end{array}$} & \multirow{2}{*}{$\begin{array}{l}\text { Fruit yield } \\
\left(\text { kg plant }^{-1}\right)\end{array}$} & \multirow{2}{*}{$\begin{array}{l}\text { Fruit yield } \\
\left(\mathrm{q} \mathrm{ha}^{-1}\right)\end{array}$} \\
\hline & 40 DAT & 60 DAT & 40 DAT & 60 DAT & & & & \\
\hline $\mathrm{T}_{0}-$ Control & 1.10 & 2.21 & 20.10 & 24.00 & 702.90 & 11.34 & 1.38 & 324.01 \\
\hline $\mathrm{T}_{1}-\mathrm{GA}_{3} 25 \mathrm{ppm}$ & 1.60 & 2.50 & 22.57 & 26.63 & 760.05 & 18.23 & 1.50 & 355.00 \\
\hline $\mathrm{T}_{2}-\mathrm{GA}_{3} 50 \mathrm{ppm}$ & 1.70 & 2.70 & 24.73 & 31.10 & 802.40 & 18.56 & 1.58 & 377.00 \\
\hline $\mathrm{T}_{3}-\mathrm{GA}_{3} 100 \mathrm{ppm}$ & 1.90 & 2.82 & 28.90 & 33.17 & 768.93 & 18.11 & 1.54 & 365.33 \\
\hline $\mathrm{T}_{4}$ - IAA $25 \mathrm{ppm}$ & 1.30 & 2.50 & 35.53 & 37.53 & 743.72 & 15.89 & 1.47 & 346.33 \\
\hline $\mathrm{T}_{5}$ - IAA $50 \mathrm{ppm}$ & 1.40 & 2.60 & 37.00 & 38.90 & 742.70 & 13.00 & 1.46 & 348.33 \\
\hline $\mathrm{T}_{6}-\mathrm{IAA} 100 \mathrm{ppm}$ & 1.40 & 2.30 & 38.00 & 39.89 & 724.72 & 12.67 & 1.44 & 338.00 \\
\hline $\mathrm{T}_{7}$-NAA $25 \mathrm{ppm}$ & 1.40 & 2.64 & 33.80 & 35.70 & 728.90 & 14.56 & 1.42 & 333.03 \\
\hline $\mathrm{T}_{8}-\mathrm{NAA} 50 \mathrm{ppm}$ & 1.50 & 2.70 & 42.60 & 44.50 & 717.54 & 14.11 & 1.41 & 332.01 \\
\hline $\mathrm{T}_{9}$ - NAA $100 \mathrm{ppm}$ & 1.50 & 2.50 & 40.37 & 42.27 & 713.34 & 11.56 & 1.40 & 329.03 \\
\hline SEm ( \pm ) & 0.13 & 0.14 & 1.46 & 1.36 & 6.38 & 0.84 & 0.01 & 1.54 \\
\hline $\mathrm{CD}(\mathrm{P} \leq 0.05)$ & 0.32 & 0.34 & 3.08 & 2.86 & 13.43 & 1.82 & 0.02 & 3.26 \\
\hline
\end{tabular}

DAT: Days after transplanting. 
The Chlorophyll content index increased with advancement of plant growth till 60 DAT. The maximum chlorophyll content was recorded at NAA at 50 ppm while the minimum chlorophyll content was found in control (Table 1). The highest chlorophyll content with the application of NAA was observed by Ramesh and Ramprasad (2013) in soybean. It might be due to decline in chlorophyll degradation because of the protection of chlorophyll molecule from photo oxidation and increased chlorophyll synthesis. Similar results were reported by Prakash et al. (2003) in black gram and Rajesh et al. (2014) in green gram.

\section{Effect on yield parameters}

The data depicted in Table 1 indicted that significant differences in respect to number of fruit per plant and fruit yield were observed due to different growth regulator treatments. Maximum number of fruit per plant and fruit yield was observed with $\mathrm{GA}_{3}$ at 50 ppm while the minimum was found under control (Table 1). The results are also corroborated to that of Hidayatullah et al. (2012). This might be due to better fruit setting. The increase in the number of fruits were associated with increased production of flower, coupled with the reduction in flower and fruit drop that ultimately increased the percentage of fruit set (Prasad et al. 2013). Similar results were reported by Choudhury et al. (2013) and Akand et al. (2015) in tomato.

\section{CONCLUSION}

It is concluded from the experiments that $\mathrm{GA}_{3}$ proved to be the best in improving the physiological and yield attributing parameters in brinjal as compared to other plant growth regulators like IAA and NAA, respectively.

\section{ACKNOWLEDGEMENTS}

Authors are thankful to Department of Horticulture, Biswanath College of Agriculture, Assam Agricultural University, Biswanath Chariali-784176, Sonitpur for financial and logistic support.

\section{REFERENCES}

Akand, H., Khairul Mazed, H.E.M., Pulok, Md. A.I., Chowdhury, Md. Shah. N. and Moonmoon, J.F. 2015. Growth and yield of tomato (Lycopersicon esculentum Mill.) as influenced by different levels of gibberelic acid application. International Journal of Applied Research, 1 (3): 71-74.

Bhatia, K.H., Kausar, N., Rashid, U., Hussain, K., Nawaz, K. and Hussain Siddiqi, E. 2013. Effect of Biotic stresses on Eggplant. World Applied Sciences Journal, 26: 302-311.

Chatterjee, R. and Choudhuri, P. 2012. Influence of foliar application of plant growth promoters on growth and yield of vegetable cowpea (Vigna unguiculata L.) Journal of Crop and Weed, 8: 158-159.

Choudhury, S., Islam.N., Sarkar, M.D. and Ali, M.A. 2013. Growth and Yield of Summer Tomato as influenced by Plant Growth Regulators. International Journal of Sustainable Agriculture, 5: 25-28.

Gopalan, C., Rama Sastri, B.V. and Balasubramanian, S. 2007. Nutritive Value of Indian Foods, published by National Institute of Nutrition (NIN), ICMR (www.icmr.nic.in)

Hidayatullah, T. Mahmood, Farooq, M., Khokhar, M.A. and Hussain, S.I. 2012. Plant Growth Regulator Affecting Sex Expression of Bottle gourd (Lagenaria siceraria Molina.). Pakistan Journal of Agricultural Sciences, 25: 50-54.

Hoque, M. and Haque, S. 2002. Effect of GA3 of physiological contributing characters of Mung bean (Vigna radiata L). Pakistan Journal of Biological Sciences, 5: 401-403.

Kaur, S., Bal, S.S., Singh, G., Sidhu, A.S. and Dhillon, T.S. 2004. Management of brinjal shoot and fruit borer, Leucinodes orbanates Guenee through net house cultivation. Acta Horticulturae, 659: 345-350.

Prakash, M., Siddesh Kumar, J. Kannan, Senthil Kumar, M. and Ganesnan, J. 2003. Effect of plant growth regulators on growth, physiology and yield of black gram. Legume Research, 26: 183-187.

Prasad, R.N., Singh, S.K., Yadava, R.B. and Chaurasia, S.N.S. 2013. Effect of $\mathrm{GA}_{3}$ and NAA on growth and yield of tomato (Lycopersicon esculentum Mill). Vegetable Science, 40: 195-197.

Rahman, S., Islam, N., Tahar, Md. A. And Abdul Karim, M. 2004. Effect of Gibberellic Acid on Growth, Quality and Yield of Tomato (Lycopersicon esculentum Mill.). Pakistan Journal of Biological Sciences, 7: 1851-1857.

Rajesh, K., Reddy, S., Reddy, A.P.K. and Singh, B.G. 2014. Effect of plant growth regulating compound on chlorophyll photosynthetic rate and yield of green gram. International Journal of Development Research, 4:1110-1112.

Ramesh, R. and Ramprasad, E. 2013. Effect of Plant growth regulators on Morphological, Physiological and Biochemical parameters of Soybean (Glycine max L.) Helix, 6:441-447. 
